\title{
Correction to: An International Journal of Plant Biology
}

Published online: 17 April 2019

(C) The Author(s) 2019

\section{Correction to: Planta https://doi.org/10.1007/s00425-019-03091-9, https://doi.org/10.1007/s00425-019-03117-2}

The articles listed above were initially published with incorrect copyright information.

Upon publication of this Correction, the copyright of these articles changed to "The Author(s)".

The original articles have been corrected.
Open Access This article is distributed under the terms of the Creative Commons Attribution 4.0 International License (http://creativeco mmons.org/licenses/by/4.0/), which permits unrestricted use, distribution, and reproduction in any medium, provided you give appropriate credit to the original author(s) and the source, provide a link to the Creative Commons license, and indicate if changes were made.

Publisher's Note Springer Nature remains neutral with regard to jurisdictional claims in published maps and institutional affiliations.

The original articles can be found online at https://doi. org/10.1007/s00425-019-03091-9 and https://doi.org/10.1007/ s00425-019-03117-2. 